\title{
PROSPEK PEMANFAATAN LEMPUNG FORMASI MUARAENIM DAN TUF FORMASI RANAU SEBAGAI BAHAN BAKU KERAMIK DI KABUPATEN OGAN KOMERING ULU SELATAN, PROVINSI SUMATERA SELATAN
}

THE PROSPECT OF CLAY DEPOSIT FROM MUARAENIM FORMATION AND TUFF FROM RANAU FORMATION AS CERAMIC RAW MATERIAL IN OGAN KOMERING ULU SELATAN REGENCY, SOUTH SUMATERA PROVINCE

\author{
Bayu Sayekti dan Penny Oktaviani \\ Pusat Sumber Daya Geologi \\ Jalan Soekarno-Hatta No. 444, Bandung \\ Email : sayekti_bayu@yahoo.co.id; penny.oktaviani@gmail.com
}

Diterima : 2 Maret 2015

Direvisi : 27 April 2015

Disetujui : 13 Mei 2015

\begin{abstract}
ABSTRAK
Endapan lempung Formasi Muaraenim di daerah Kabupaten Ogan Komering Ulu Selatan terdapat sebagai overburden di bagian atas lapisan batubara, dan sebagai interburden di antara dua lapisan batubara. Formasi Ranau terdiri dari tuf riolitan, tuf batuapung, tuf padu dengan sisipan batulempung berkarbon.

Berdasarkan evaluasi hasil pengujian awal melalui pembakaran pada suhu tinggi $1.400^{\circ} \mathrm{C}$ menunjukkan bahwa lempung dari Formasi Muaraenim di daerah penyelidikan dapat digunakan sebagai bahan baku keramik bodi stoneware, sedangkan felspar diagenetik (tuf feldspatik) dapat dimanfaatkan untuk bahan pelebur (flux) dalam bodi keramik pada proses pembakaran.

Percobaan prototip ubin, dengan rasio komposisi campuran lempung dan felspar diagenetik (tuf feldspatik) $1: 1$ menunjukkan hasil dapat dibuat ubin keramik berglasir kelas II berbasis bodi "stone ware" dengan suhu pembakaran $1.150^{\circ} \mathrm{C}$. Sumberdaya lempung dan felspar yang cukup berlimpah ini dapat dimanfaatkan dan prospek untuk dikembangkan sebagai bahan baku alternatif siap pakai untuk industri keramik.
\end{abstract}

Kata kunci: lempung, felspar, bahan keramik.

\begin{abstract}
Clay deposit of Muaraenim Formation in Ogan Komering Ulu Selatan Regency is found as overburden on top of coal seam, and as interburden among two coal seams. Ranau Formation consists of rhyolitic tuff, pumice tuff, and tuff intercalation with carbonize claystone.

Early result through high temperature combustion at $1,400^{\circ} \mathrm{C}$ shows that clay from Muaraenim Formation in study area can be utilized as stoneware ceramic body, while diagenetic feldspar (feldsphatic tuff) can be utilized as fusion material (flux) for ceramic body in the combustion process.

Tile prototype analysis with composition ratio of clay and diagenetic feldspar (feldsphatic tuff) $1: 1$ shows that within combustion temperature $1,150^{\circ} \mathrm{C}$, it can produce grade II of glazing ceramic tile based on stoneware body. This abundant clay and felsdpar resources can be utilized and developed for ready-made alternative raw material in ceramic industry.
\end{abstract}

Keywords: clay, feldspar, ceramic material.

\section{PENDAHULUAN}

Ketersediaan bahan baku merupakan salah satu faktor penting untuk kelangsungan hidup industri keramik. Pada tahun 2014, industri keramik Indonesia memiliki kapasitas 1,8 juta $\mathrm{m}^{2} /$ hari dan produksi 1,6 juta $\mathrm{m}^{2} /$ hari. Hasil produksi sebanyak $87 \%$ diserap pasar lokal dan $13 \%$ lainnya diekspor, dengan nilai penjualan industri keramik mencapai Rp 30 triliun dan diproyeksikan pada tahun 2015 mencapai Rp 36 triliun atau meningkat 20\% (http://www.kemenperin. go.id/artikel/8999/Kapasitas-IndustriKeramik-Terus-Diperluas). 
Penduduk Indonesia yang mencapai 250 juta jiwa dinilai menjadi peluang pasar yang besar bagi industri keramik nasional. Hal itu seiring dengan pertumbuhan pasar dalam negeri yang terus meningkat, terutama untuk jenis floor tile atau ubin, karena didukung oleh pertumbuhan pembangunan properti maupun perumahan.

Penelitian ini dimaksudkan untuk mengetahui prospek pemanfaatan felspar pada satuan tuf Formasi Ranau dan lempung sedimen yang dijumpai sebagai overburden dan interburden lapisan batubara dari Formasi Muaraenim. Tuf Formasi Ranau ditemukan di daerah Simpang Sender Utara, Kecamatan Buay Pematang Ribu Ranau Tengah, daerah Sukarami dan Mehanggin serta Pelangki, Kecamatan Muaradua. Lempung sedimen dijumpai di daerah Simpang Sender Utara, Kecamatan Buay Pematang Ribu Ranau Tengah, daerah Campang dan Sipin, Kecamatan Muaradua, Kabupaten Ogan Komering Ulu Selatan, Provinsi Sumatera Selatan (Gambar 1).

\section{GEOLOGI DAN BAHAN BAKU KERAMIK}

Daerah penelitian termasuk ke dalam Peta Geologi Lembar Baturaja, Sumatera, skala 1 : 250.000 (Gafoer, dkk, 1993). Batuan yang terdapat di daerah ini sangat beragam dari batuan volkanik, batuan beku, batuan sedimen dan batuan malihan dari berbagai umur. Formasiformasi batuan yang terdapat di daerah penyelidikan yang cukup potensial sebagai bahan baku keramik terdapat pada Formasi Muaraenim, Formasi Ranau, Satuan Batuan Gunung Api dan Satuan Breksi.

Formasi Muaraenim (Tmpm), formasi ini terdiri dari batulempung yang berwarna coklat sampai hitam, keras, dengan sisipan batubara, diperkirakan berumur Miosen Akhir-Pliosen Awal. Formasi batuan ini tersebar di bagian tengah wilayah penyelidikan memanjang berarah utara - selatan, dijumpai di daerah perbatasan Plangki dan Serakat (Kecamatan Muaradua), Ruos, Pelawi
(Kecamatan Buay Rawan) dan Simpang Sender Utara (Kecamatan Buay Pematang Ribu Ranau Tengah), membentuk perbukitan bergelombang. Lempung di daerah ini sama sekali belum dimanfaatkan.

Formasi Ranau (QTr), terdiri dari tuf riolitan, tuf batuapung, tuf padu dengan sisipan batulempung berkarbon, diperkirakan berumur Plio-Plistosen. Formasi ini diendapkan tak selaras diatas formasi-formasi yang lebih tua, menjemari sebagian dengan Formasi Kasai.

Satuan Batuan Gunungapi (Qv), terdiri dari lava, tuf dan breksi gunungapi bersusunan andesit-basal, diperkirakan berumur Plistosen Akhir. Berdasarkan pengamatan satuan ini tersebar di bagian barat dan baratdaya dari daerah penyelidikan, tersebar berarah baratlauttenggara, satuan ini terdiri dari boulderboulder andesit-basal serta breksi gunungapi. Lapukan breksi ini berupa lempung berwarna abu-abu kemerahan, liat dan lengket jika kena air, tersingkap di daerah perbukitan termasuk ke dalam wilayah Kecamatan Buay Pemaca.

Satuan Breksi (Qhv), terdiri dari breksi gunungapi, lava dan tuf bersusunan andesit-basal, diperkirakan berumur Plistosen-Holosen. Berdasarkan pengamatan di lapangan satuan ini berkomposisi hampir sama dengan Satuan Batuan Gunungapi, yang susunannya berupa bongkah-bongkah andesit-basal serta breksi gunungapi. Pelapukannya berupa lempung berwarna merah, liat dan lengket jika kena air. Satuan batuan ini tertutup tuf yang diperkirakan berasal dari Formasi Ranau, dijumpai di daerah Kisam Ilir, tersebar di bagian baratlaut dan tenggara lokasi penelitian berarah barat-timur.

Keramik adalah berbagai produk seni, sains dan teknologi yang dibuat dari campuran bahan tambang/galian anorganik non logam seperti lempung, felspar, kaolin dan pasirkuarsa yang dalam prosesnya mengalami pembakaran suhu tinggi, mempunyai struktur kristalin, non kristalin atau campuran dari keduanya. Sifat keramik sangat ditentukan oleh struktur kristal, komposisi kimia dan 
mineral bawaannya. Oleh karena itu sifat keramik juga tergantung pada lingkungan geologi tempat bahan diperoleh. Bahan baku keramik yang umum dipakai adalah lempung, felspar, ball clay, kuarsa dan kaolin (Praptopo Sumitro, 1984 dalam Agus Mulyadi Utomo, 2007).

Felspar merupakan mineral alumina silikat yang kaya akan kalium dan natrium, merupakan turunan dari kelompok mineral plagioklas yang berkomposisi asam. Batuan granit, genes dan pegmatit merupakan sumber dari felspar, selain itu dapat dijumpai dalam granodiorit dan tufa riolitik. Felspar merupakan salah satu komoditi mineral bukan logam yang penting guna memenuhi kebutuhan di bidang industri keramik. Mutu felspar ditentukan oleh kandungan $\mathrm{Na}_{2} \mathrm{O}$ dan $\mathrm{K}_{2} \mathrm{O}$ yang relatif tinggi $(>6 \%), \quad \mathrm{Fe}_{2} \mathrm{O}_{3}$ dan $\mathrm{TiO}_{2}$
(Sukandarrumidi, 1999). Pada umumnya felspar diolah dengan menghilangkan unsur pengotor seperti besi, biotit, turmalin, mika dan kuarsa. Apabila unsur $\mathrm{Fe}_{2} \mathrm{O}_{3}$ terlalu tinggi akan mengakibatkan perubahan warna pada proses pembuatan badan keramik $\left(\mathrm{Fe}_{2} \mathrm{O}_{3}\right.$ maksimum $\left.0,30 \%\right)$. Jenis felspar yang digunakan dalam industri keramik adalah ortoklas/mikroklin dan albit/plagioklas asam (natrium felspar), sedangkan yang basa dengan kadar kalium tinggi jarang dipakai. Persyaratan mutu felspar untuk pembuatan body keramik dan glasir dapat dilihat pada Tabel 1 dan Tabel 2 . Pengujian sifat fisik perlu dilakukan dengan metoda uji bakar keramik pada suhu $1.400^{\circ} \mathrm{C}$, setelah pembakaran kemudian diamati kepadatan, warna dan homogenitas leburan.

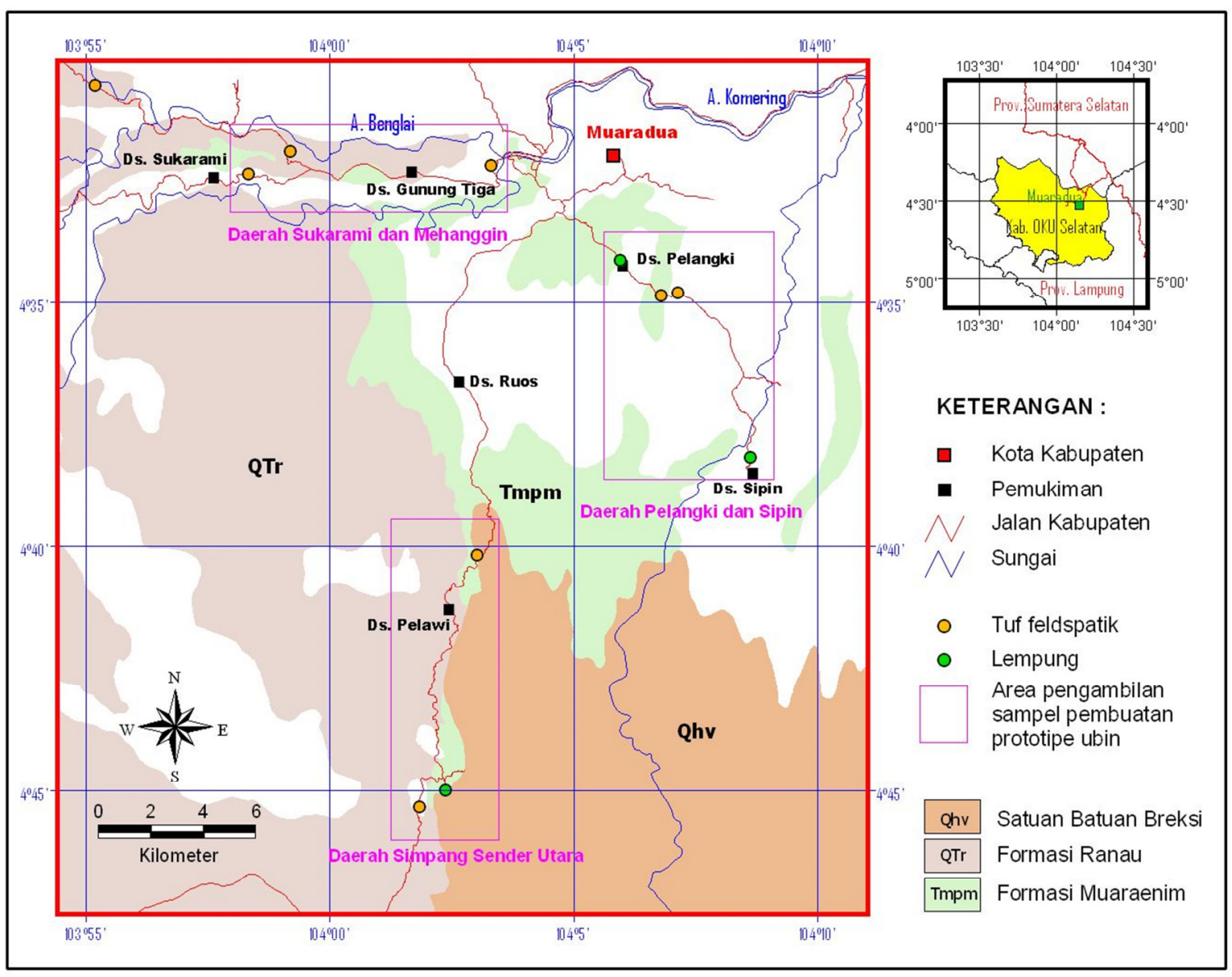

Gambar 1. Peta lokasi pemercontoan dan sebaran formasi pembawa bahan baku keramik 


\section{MAKALAH ILMIAH}

Tabel 1. Syarat mutu felspar untuk pembuatan badan keramik halus (SNI 15-0926-1996)

\begin{tabular}{cccc}
\hline Komposisi & \multicolumn{3}{c}{ Felspar Sebagai Bahan Baku } \\
\cline { 2 - 4 } \multicolumn{1}{c}{ Kimia } & Porselin (\%) & Gerabah padat (\%) & Gerabah keras (\%) \\
\hline $\mathrm{K}_{2} \mathrm{O}+\mathrm{Na}_{2} \mathrm{O}$ & $10-16,9$ & $6-10$ & $4-6$ \\
$\mathrm{Fe}_{2} \mathrm{O}_{3}$, maks & 0,5 & 1 & 1 \\
$\mathrm{Ti}_{2} \mathrm{O}$, maks & 0,3 & - & - \\
\hline
\end{tabular}

Tabel 2. Syarat mutu felspar untuk glasir (SII No. $1275-1985)$

\begin{tabular}{ccc}
\hline Kelas & Kadar $\mathrm{Na}_{\mathbf{2}} \mathbf{O}(\%)$ & Kadar $\mathrm{Fe}_{\mathbf{2}} \mathbf{O}_{3}(\%)$ \\
\hline 1 & $2,00-2,99$ & Maksimum 0,3 \\
2 & $3,00-3,99$ & untuk semua kelas \\
3 & $4,00-4,99$ & \\
4 & $5,00-5,99$ & \\
5 & $6,00-6,99$ & \\
\hline
\end{tabular}

Lempung dikelompokkan menjadi dua bagian besar, yaitu (Sukandarrumidi, 1999) :

1) Lempung residu, terbentuk karena proses pelapukan batuan beku, sedimen maupun malihan dan ditemukan di sekitar batuan induknya.

2) Lempung sedimen, sering disebut tanah liat ini didasarkan atas sifatnya yang liat bila terkena air, merupakan hasil desintegrasi, pelapukan kimia terutama pengaruh $\mathrm{H}_{2} \mathrm{O}$ dan $\mathrm{CO}_{2}$ dibantu mikroorganisme terhadap batuan induk.

Mutu lempung residu umumnya lebih baik dari lempung sedimen, dengan komposisi didominasi oleh mineral illit dan umumnya digunakan untuk pembuatan batubata, genteng dan gerabah.

Bahan mentah keramik menurut fungsinya dalam bodi digolongkan menjadi 4 (empat), yaitu sebagai:

1) Bahan Pengikat, seperti kaolin, ball clay, fire clay, red clay

2) Bahan Pelebur, seperti felspar, kapur

3) Bahan Pengisi, seperti silika, grog (samot)

4) Bahan Tambahan, seperti water glass, talk, pirofilit

\section{METODE PENELITIAN}

Metoda penelitian yang digunakan meliputi penelitian lapangan, analisis laboratorium serta pengolahan data. Penelitian lapangan berupa pengamatan singkapan dan hubungannya dengan formasi pembawa bahan galian keramik, serta pengambilan perconto lempung dan felspar diagenetik. Endapan lempung diambil dari sumur uji, berupa lapisan overburden dari batubara, sedangkan endapan felspar diagenetik diambil dengan metode chip sampling.

Analisis laboratorium meliputi analisis kimia unsur utama (major element) dan analisis keramik meliputi: analisis bakar pendahuluan atau yang dikenal dengan PS 14, analisis bakar teknologi dan pembuatan prototype. Analisis kimia unsur utama dilakukan untuk mengetahui kandungan unsur-unsur utama dari conto lempung dan felspar diagenetik, hal ini penting khususnya untuk menentukan kualitas dari lempung dan felspar diagenetik. Analisis bakar pendahuluan dilakukan untuk mengetahui sifat-sifat keramik dari lempung dan felspar diagenetik. Analisis ini dilakukan dengan cara membakar conto lempung dan felspar diagenetik dengan suhu mencapai $1.400^{\circ} \mathrm{C}$, yang diamati adalah kepadatan hasil bakar, massa gelas, homogenitas leburan dan warna. Analisis bakar teknologi dilakukan dengan cara membakar prototipe ubin pada suhu $1.050^{\circ} \mathrm{C}$ dan $1.150^{\circ} \mathrm{C}$, yang diamati adalah susut kering, susut bakar, susut jumlah, peresapan air dan kuat lentur.

\section{HASIL DAN PEMBAHASAN}

Formasi Ranau tersebar sangat luas di bagian tengah dari daerah penyelidikan, tersebar berarah baratlauttenggara, dijumpai di daerah Kecamatan 
Buay Sandang Aji, Kecamatan Runjung Agung, Kecamatan Buay Rawan, Kecamatan BPR Ranau Tengah, dan Kecamatan Pulau Beringin. Tuf dari formasi ini berwarna putih keabu-abuan, rapuh-keras, banyak dijumpai mika, umumnya menempati daerah pematang tinggi jalan dan daerah perbukitan yang masih ditumbuhi semak belukar dan tanaman keras. Berdasarkan analisis petrografi, mempunyai komposisi kuarsa $10 \%$, plagioklas $3 \%$, opal/oksida besi $5 \%$, biotit 10\%, gelas $30 \%$ dan mineral lempung $42 \%$. Lapukan lanjut dari batuan tuf yang berupa lempung sudah diusahakan oleh masyarakat di daerah Talang Sawah, Desa Pelangki, Kecamatan Muaradua sebagai bahan baku pembuatan batubata dengan harga Rp 500-550/bata di tempat. Sumberdaya hipotetik felspar diagenetik (tuf felspatik dari Formasi Ranau) sebesar 13.776.000 ton (Sayekti, dkk., 2012).

Beberapa conto tuf felspar diambil untuk dianalisis kimia dan keramik. Adapun lokasi pengambilan conto adalah: di Desa Negeri Agung, Kecamatan Buay Sandang Aji, di Desa Simpang Pedagan, Kecamatan Muaradua (Gambar 2), di Talang Nangka, Desa Simpang Sender Utara, Kecamatan Buay Pematang Ribu Ranau Tengah, di Desa Mehanggin, Kecamatan Muaradua, di Desa Pulau
Beringin, Kecamatan Pulau Beringin, di Desa Campang, Kecamatan Kisam Ilir, di Desa Tanjung Iman, Kecamatan Buay Sandang Aji, di Desa Kenali, Kecamatan Buay Sandang Aji, di Desa Sukarami, Kecamatan Buay Sandang Aji), di Desa Serakat Jaya, Kecamatan Buay Pemaca, dan di Desa Pelangki, Kecamatan Muaradua. Hasil analisis kimia terhadap conto tuf felspatik di daerah tersebut menunjukkan kandungan $\mathrm{SiO}_{2} 68,36 \%$ s.d. $73,39 \% ; \mathrm{Al}_{2} \mathrm{O}_{3} 10,86 \%$ s.d. $13,96 \% ; \mathrm{Fe}_{2} \mathrm{O}_{3}$ $1,80 \%$ s.d. $5,30 \% ; \quad \mathrm{Na}_{2} \mathrm{O} \quad 1,85 \%$ s.d. 3,92\%; dan $\mathrm{K}_{2} \mathrm{O} 2,59 \%$ s.d. $4,43 \%$.

Berdasarkan hasil analisis kimia dan bakar/keramik felspar dari tuf Formasi Ranau dapat digunakan sebagai glasir kelas $1\left(\mathrm{Na}_{2} \mathrm{O} 2,96 \%\right)$ dan glasir kelas 2 $\left(\mathrm{Na}_{2} \mathrm{O} 3,11 \%\right.$ s.d. 3,86\%) (Tabel 2) dan sebagai bahan baku gerabah kasar/earthenware, gerabah padat/stoneware dan pelebur (Tabel 3). Tuf felspatik tersebut, sebelum digunakan sebaiknya perlu dilakukan proses pengolahan (benefisiasi) guna menghilangkan mika dan kuarsa serta menurunkan kadar oksida pengotornya $\left(\mathrm{Fe}_{2} \mathrm{O}_{3}\right)$ sampai dengan persyaratan yang ditentukan sebagai bahan baku pembuatan badan keramik serta pelebur. Oksida pengotor $\left(\mathrm{Fe}_{2} \mathrm{O}_{3}\right)$ yang berada di dalam tuf felspatik tersebut relatif cukup tinggi berkisar dari $1 \%$ s.d. $5 \%$.

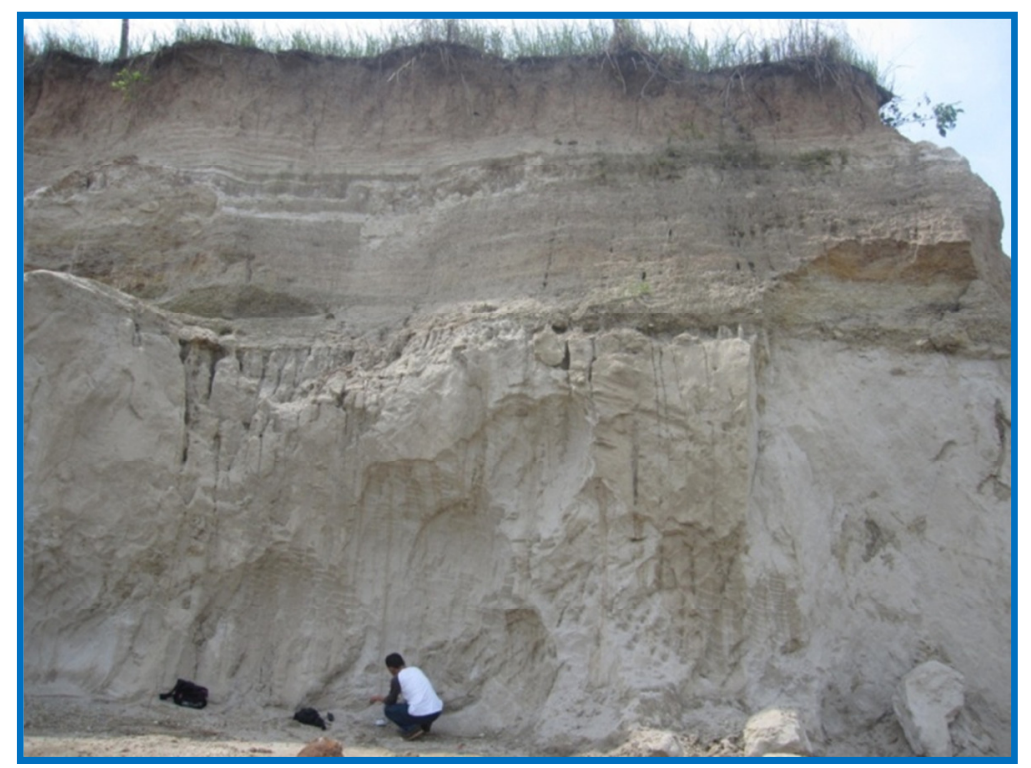

Gambar 2. Singkapan felspar diagenetik dari tuf Ranau di Desa Simpang Pedagan, Kecamatan Muaradua 


\section{MAKALAH ILMIAH}

Tabel 3. Hasil uji bakar (sifat-sifat keramik) dari tuf feldspatik pada suhu $1.400^{\circ} \mathrm{C}$

\begin{tabular}{|c|c|}
\hline Daerah & Keterangan \\
\hline $\begin{array}{l}\text { PT MBH } \\
\text { Mineral } \\
\text { Resources, } \\
\text { Desa Pelawi }\end{array}$ & $\begin{array}{l}\text { Hasil evaluasi : bodi sudah } \\
\text { padat, tidak porous, massa } \\
\text { gelas sudah melebur } \\
\text { sempurna, warna bakar } \\
\text { hitam kecoklatan bintik } \\
\text { oranye, permukaan halus } \\
\text { dan mengkilat, cocok untuk } \\
\text { bodi earthenware dengan } \\
\text { suhu bakar }<1.000^{\circ} \mathrm{C} \text {. }\end{array}$ \\
\hline $\begin{array}{l}\text { Talang Nangka, } \\
\text { Desa Simpang } \\
\text { Sender Utara }\end{array}$ & $\begin{array}{l}\text { Hasil evaluasi : bodi sudah } \\
\text { padat, warna bakar coklat } \\
\text { keabu-abuan bintik hitam } \\
\text { dan oranye, massa gelas } \\
\text { melebur sempurna, } \\
\text { kemungkinan cocok untuk } \\
\text { bodi earthenware dengan } \\
\text { suhu bakar }<1.000^{\circ} \mathrm{C} \text {. }\end{array}$ \\
\hline
\end{tabular}

\begin{tabular}{ll}
\hline $\begin{array}{l}\text { Desa } \\
\text { Mehanggin }\end{array}$ & $\begin{array}{l}\text { Hasil evaluasi : bodi sudah } \\
\text { melebur sempurna, warna } \\
\text { bakar coklat keabu-abuan, } \\
\text { homogenitas leburan } \\
\text { merata, massa gelas } \\
\text { banyak, kemungkinan cocok } \\
\text { untuk bodi earthenware } \\
\text { dengan suhu bakar < } \\
1.000^{\circ} \mathrm{C} .\end{array}$ \\
\hline Desa Sukarami & $\begin{array}{l}\text { Hasil evaluasi : bodi sudah } \\
\text { melebur sempurna, warna } \\
\text { bakar abu-abu kecoklatan, } \\
\text { kemungkinan cocok untuk } \\
\text { bahan pelebur. }\end{array}$ \\
\hline
\end{tabular}

Endapan lempung sebagai bahan baku keramik dijumpai di bagian tengah daerah penelitian, di daerah IUP Eksplorasi PT. Anugrah Energi, Desa Simpang Sender Utara, Kecamatan Buay Pematang Ribu Ranau Tengah, dari lubang sumur uji, dijumpai endapan lempung sebagai overburden dan interburden pada lapisan batubara dari Formasi Muaraenim (Gambar 3). Sumberdaya hipotetik lempung di daerah ini sebesar $8.441 .000 \mathrm{~m}^{3}$ atau setara dengan 14.771.750 ton (Sayekti, dkk., 2012).
Hasil analisis kimia terhadap conto lempung di daerah ini menunjukkan kandungan $\mathrm{SiO}_{2} 63,34 \% ; \mathrm{Al}_{2} \mathrm{O}_{3} 18,40 \%$; $\mathrm{Fe}_{2} \mathrm{O}_{3} 3,45 \%$ dan $\mathrm{MgO}$ 0,42\%, sedangkan hasil analisis bakar (Tabel 4) menunjukkan bahwa lempung di daerah ini mempunyai pori cukup banyak, massa gelas belum terbentuk, belum lebur, warna bakar coklat kemerah-merahan, kemungkinan cocok untuk bahan baku keramik bodi stoneware dengan suhu bakar $1.100^{\circ} \mathrm{C}$ s.d. $1.250^{\circ} \mathrm{C}$. 


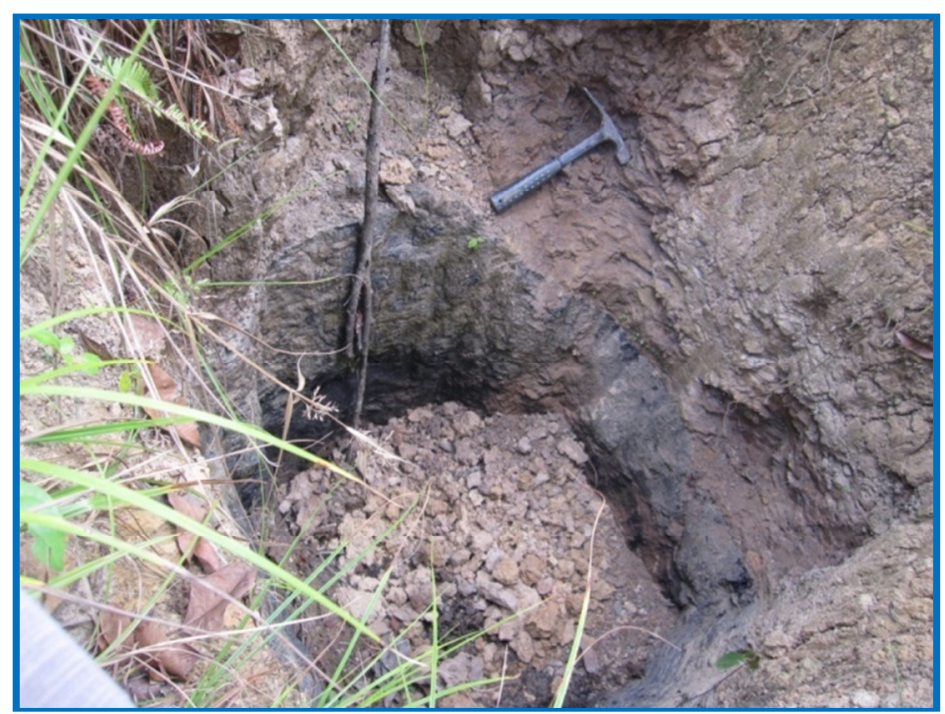

Gambar 3. Singkapan lempung sedimen Formasi Muaraenim, di daerah sekitar IUP Eksplorasi batubara PT. Anugrah Energi diambil dari lubang sumur uji

Tabel 4. Uji coba bakaran sifat keramik dari lempung

\begin{tabular}{ll}
\hline \multicolumn{1}{c}{ Daerah } & \multicolumn{1}{c}{ Keterangan } \\
\hline PT. Anugrah & Hasil evaluasi : pori \\
Energi, Desa & cukup banyak, massa \\
Simpang & gelas belum terbentuk, \\
Sender Utara & belum lebur, warna \\
& bakar coklat tua, \\
& kemungkinan cocok \\
& untuk bodi stoneware \\
& dengan suhu bakar \\
& $1.100^{\circ} \mathrm{C}$ s.d. $1.250^{\circ} \mathrm{C}$. \\
\hline
\end{tabular}

Lempung sebagai bahan baku keramik di daerah ini, selain dijumpai sebagai lempung sedimen, terdapat pula lempung residual hasil pelapukan dari Satuan Batuan Gunungapi, dapat dijumpai di Desa Sipin, Kecamatan Buay Pemaca. Hasil analisis kimia terhadap conto lempung di daerah ini menunjukkan kandungan $\mathrm{SiO}_{2} 49,84 \% ; \mathrm{Al}_{2} \mathrm{O}_{3} 21,08 \%$ dan $\mathrm{Fe}_{2} \mathrm{O}_{3} 12,16 \%$, sedangkan hasil analisis bakar menunjukkan bahwa lempung di daerah ini mempunyai bodi sangat porous, warna bakar merah tua kecoklatan, permukaan retak-retak, bersifat tahan api rendah, kemungkinan cocok untuk barang tahan api suhu rendah.

Setelah dilakukan uji bakaran sifatsifat keramik dan diketahui hasil evaluasinya, maka dilakukan uji coba untuk pembuatan prototipe berupa ubin $(10 \mathrm{~cm} \times 10 \mathrm{~cm})$ yang merupakan pencampuran conto lempung dan tuf felspatik dengan perbandingan $1: 1(50 \%$ lempung dan $50 \%$ felspar). Sebagai bahan baku pembuatan ubin keramik felspar berfungsi untuk menghasilkan ubin lebih tahan terhadap retakan (cracking) dan mengurangi susut. Sedangkan lempung karena sifat keplastisannya memudahkan pembentukan rangka/body ubin tersebut. Prototipe ubin ini dibakar dengan suhu $1.050^{\circ} \mathrm{C}$ dan $1.150^{\circ} \mathrm{C}$.

Sifat-sifat keramik diamati setelah proses pembakaran pada suhu $1.050^{\circ} \mathrm{C}$ dan $1.150^{\circ} \mathrm{C}$ selesai. Sifat-sifat keramik yang diamati adalah kepadatan, warna bakar dan kehalusan permukaan. Setelah diamati, ternyata bahwa kepadatan, kehalusan permukaan dan warna bakar pada masing-masing suhu bakar $\left(1.050^{\circ} \mathrm{C}\right.$ dan $1.150^{\circ} \mathrm{C}$ ) tidak sama. Pada masingmasing suhu bakar, warna cukup bervariasi (krem-coklat kemerahan). Pada 


\section{MAKALAH ILMIAH}

kehalusan permukaan, dalam hal ini jika permukaannya agak kasar hingga kasar tidak dikehendaki dalam pembuatan ubin (Bukit, dkk, 1994). Oleh karena itu komposisi lempung dan felspar dari Desa Mehanggin (prototipe 2) tidak memenuhi syarat dalam pembuatan ubin, dikarenakan permukaan hasil pembakaran agak kasar.

Penyerapan air adalah banyaknya air yang meresap dalam benda percobaan dalam keadaan kering dan dinyatakan dalam \% dari berat air terhadap berat benda percobaan (SNI 03-2096-1991). Berdasarkan Standar Nasional Indonesia nomor 03-4062-1996 penyerapan air untuk ubin keramik jenis "stone ware" berglasir kelas I bernilai 3\% s.d. 6\%, untuk kelas II bernilai $6 \%$ s.d. $10 \%$, sedangkan penyerapan air untuk jenis "earthenware" $>10 \%$ (Tabel 5).

Kuat lentur adalah hasil bagi dari momen lentur yang terbesar dan momen perlawanan yang terjadi pada gaya lentur maksimum (gaya pada patahnya benda percobaan) (SNI 03-2096-1991). Persyaratan kuat lentur ubin keramik jenis "stone ware" kelas I bernilai $220 \mathrm{~kg} / \mathrm{cm}^{2}$, untuk kelas II bernilai $180 \mathrm{~kg} / \mathrm{cm}^{2}$, sedangkan kuat lentur ubin jenis "earthenware" bernilai $120 \mathrm{~kg} / \mathrm{cm}^{2}$ (SNI No 03-4062-1996) (Tabel 5).

Berdasarkan persyaratan dalam SNI No 03-4062-1996 tersebut, semua prototipe ubin pada pembakaran suhu $1.050^{\circ} \mathrm{C}$ memenuhi syarat untuk ubin jenis "earthenware", sedangkan semua prototipe ubin pada pembakaran suhu $1.150^{\circ} \mathrm{C}$ memenuhi syarat untuk ubin jenis "stone ware" berglasir kelas II (Tabel 6).

Berdasarkan persyaratan di dalam SNI No 03-4062-1996, dari hasil pengujian kuat lentur prototipe ubin pada suhu pembakaran $1.050^{\circ} \mathrm{C}$, prototipe $1(150,84$ $\mathrm{kg} / \mathrm{cm}^{2}$ ) (Gambar 4), prototipe $2(137,25$ $\mathrm{kg} / \mathrm{cm}^{2}$ ) (Gambar 5) dan prototipe 4 $\left(136,73 \mathrm{~kg} / \mathrm{cm}^{2}\right)$ (Gambar 7) memenuhi syarat untuk ubin jenis "earthenware", terkecuali untuk prototipe ubin (prototipe 3, kuat lentur $191 \mathrm{~kg} / \mathrm{cm}^{2}$ ) dengan komposisi lempung dari Desa Campang, Kecamatan Kisam llir dan tuf felspatik dari Desa Sukarami, Kecamatan Buay Sandang Aji memenuhi syarat untuk ubin jenis "stone ware" berglasir kelas II (Gambar 6) (Tabel $6)$.

Tabel 5. Syarat mutu industri ubin lantai keramik berglasir (SNI No. 03-4062-1996)

\begin{tabular}{lcccc}
\hline & Porselin & \multicolumn{2}{c}{ Stoneware } & Earthenware \\
\cline { 3 - 5 } & & $\mathrm{I}$ & $\mathrm{Il}$ & \\
\hline Penyerapan air $(\%)$ & $<3$ & 3 s.d. 6 & 6 s.d. 10 & $>10$ \\
Kuat lentur $\left(\mathrm{kg} / \mathrm{cm}^{2}\right)$ & 270 & 220 & 180 & 120 \\
\hline
\end{tabular}

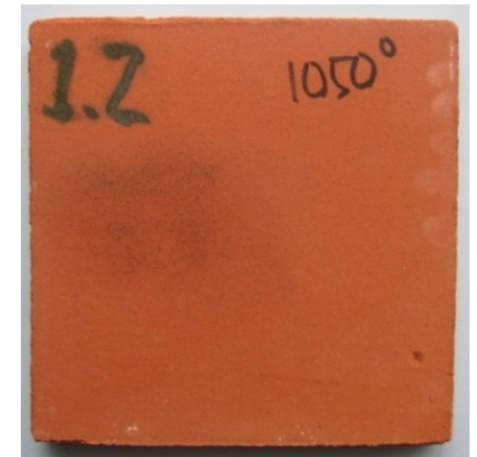

Hasil suhu pembakaran $1.050^{\circ} \mathrm{C}$

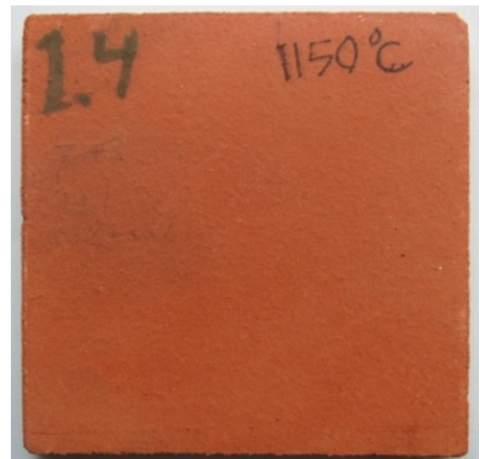

Hasil suhu pembakaran $1.150^{\circ} \mathrm{C}$

Lempung desa Simpang Sender Utara (50\%) + Tuf Feldspatik desa Simpang Sender Utara $(50 \%)$ (Prototipe 1)

Gambar 4. Hasil bakar prototipe ubin Desa Simpang Sender Utara 


\section{MAKALAH ILMIAH}

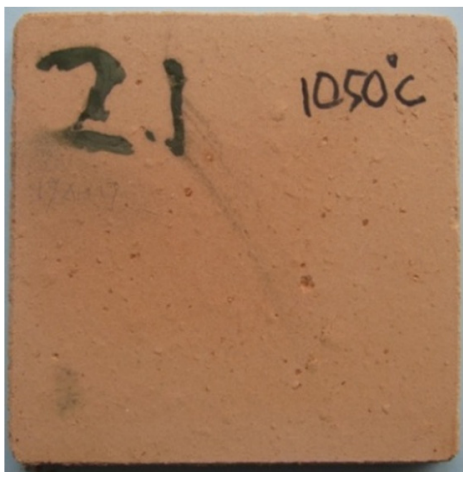

Hasil suhu pembakaran $1.050^{\circ} \mathrm{C}$

Lempung desa Mehanggin (Prototipe 2)

Gambar 5. Hasil bakar prototipe ubin Desa Mehanggin

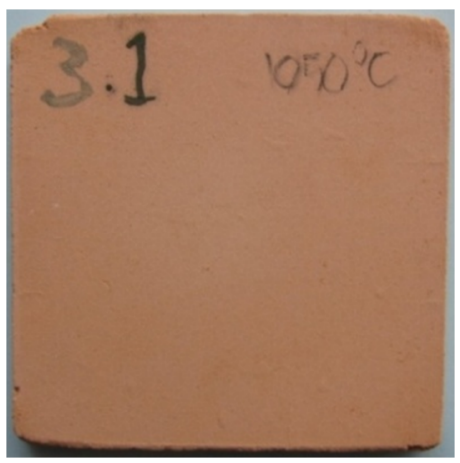

Hasil suhu pembakaran $1.050^{\circ} \mathrm{C}$ Lempung desa Campang (50\%) + Tuf Feldspatik desa Sukarami $(50 \%)$

(Prototipe 3)

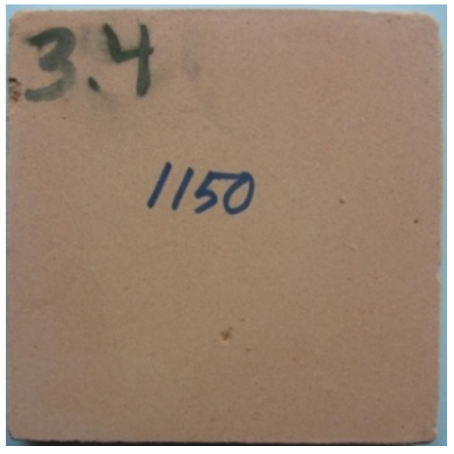

Hasil suhu pembakaran $1.150^{\circ} \mathrm{C}$

Hasil suhu pembakaran $1.150^{\circ} \mathrm{C}$

atik desa Mehanggin (50\%)

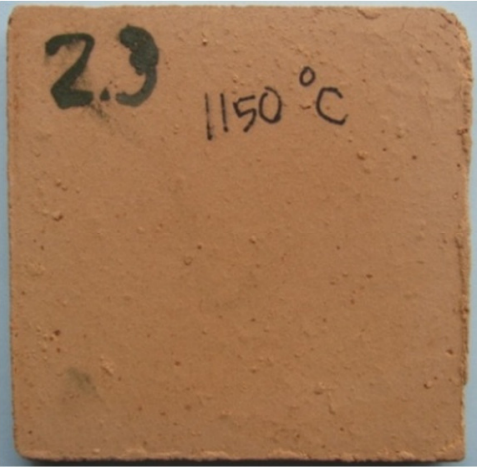

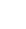


Sukarami, Kecamatan Buay Sandang Aji memenuhi syarat untuk ubin jenis "stoneware" berglasir kelas I, sedangkan prototipe ubin (prototipe 4, kuat lentur $156,39 \mathrm{~kg} / \mathrm{cm}^{2}$ ) dengan komposisi lempung dari Desa Sipin, Kecamatan Buay Pemaca dan tuf feldspatik dari Desa Pelangki, Kecamatan Muara Dua, hanya memenuhi syarat untuk ubin jenis "earthenware" (Tabel 6).

\section{KESIMPULAN DAN SARAN}

Berdasarkan evaluasi dari data hasil penyelidikan lapangan, hasil analisis laboratorium baik analisis unsur utama maupun analisis uji prototipe benda keramik serta hasil kajian dari berbagai sumber pustaka dapat disimpulkan bahwa lempung dari Formasi Muaraenim dapat digunakan sebagai bahan baku keramik bodi stoneware dengan suhu bakar $1.100^{\circ} \mathrm{C}-1.250^{\circ} \mathrm{C}$. Tuf feldspatik dapat dimanfaatkan sebagai bahan pelebur dalam proses pembuatan keramik serta untuk bodi earthenware dengan suhu bakar $<1.000^{\circ} \mathrm{C}$. Dari hasil uji teknologi pada beberapa prototipe ubin yang dibakar pada suhu $1.050^{\circ} \mathrm{C}$, memenuhi syarat untuk pembuatan ubin jenis "earthenware" (prototipe 1, prototipe 3, dan prototipe 4). Adapun bahan baku ubin yang dibakar pada suhu $1.150^{\circ} \mathrm{C}$, memenuhi syarat untuk pembuatan ubin jenis "stoneware" berglasir kelas II (prototipe 1 dan prototipe 4), terkecuali untuk ubin prototipe 3 memenuhi syarat untuk ubin jenis "stoneware" berglasir kelas I. Bahan baku ubin prototipe 2 tidak memenuhi syarat dalam pembuatan ubin, dikarenakan permukaan prototipe ubin hasil pembakaran agak kasar. Semakin tinggi suhu pembakaran maka susut bakar dan kuat lentur semakin besar, tetapi penyerapan air semakin kecil. Suhu pembakaran yang ideal untuk bahan baku keramik di daerah penelitian adalah $1.150^{\circ} \mathrm{C}$.

Melihat luasnya sebaran Formasi Muaraenim dan Formasi Ranau di Kabupaten Ogan Komering Ulu Selatan, disarankan dilakukan kegiatan yang sama pada Formasi Muaraenim dan Formasi Ranau di daerah lainnya yang kedua formasi tersebut dapat dijumpai. Hal ini sangat disarankan mengingat prospek pemanfaatan lempung dari Formasi Muaraenim dan tuf felspatik dari Formasi Ranau sebagai bahan baku keramik yang cukup baik.

Tabel 6. Data uji fisik (sifat teknologis) benda coba untuk pembuatan ubin keramik

\begin{tabular}{|c|c|c|c|c|c|c|c|}
\hline \multirow[b]{2}{*}{ Bahan Prototipe } & \multirow[b]{2}{*}{$\begin{array}{c}\text { Suhu } \\
\text { pembakaran }\end{array}$} & \multicolumn{5}{|c|}{ Jenis Uji } & \multirow[b]{2}{*}{$\begin{array}{l}\text { Hasil bakar } \\
\text { prototipe ubin }\end{array}$} \\
\hline & & $\begin{array}{l}\text { SK } \\
(\%)\end{array}$ & $\begin{array}{l}\text { SB } \\
(\%)\end{array}$ & $\begin{array}{l}\text { SJ } \\
(\%)\end{array}$ & $\begin{array}{l}\text { PA } \\
(\%)\end{array}$ & $\begin{array}{c}\text { Kuat Lentur } \\
\left(\mathrm{Kg} / \mathrm{cm}^{2}\right)\end{array}$ & \\
\hline \multirow{4}{*}{$\begin{array}{c}\text { Lempung Simpang } \\
\text { Sender Utara } \\
+ \\
\text { Tuf feldspatik Simpang } \\
\text { Sender Utara } \\
\text { (Prototipe 1) } \\
\end{array}$} & & \multirow{4}{*}{$-1,08$} & & & & & \\
\hline & $1.050^{\circ} \mathrm{C}$ & & 2,40 & 1,35 & 13,13 & 150,84 & kurang padat \\
\hline & & & & & & & \\
\hline & $1.150^{\circ} \mathrm{C}$ & & 5,58 & 4,55 & 8,50 & 189,01 & cukup padat \\
\hline \multirow{3}{*}{$\begin{array}{c}\text { Lempung Mehanggin } \\
+ \\
\text { Tuf feldspatik } \\
\text { Mehanggin } \\
\text { (Prototipe 2) } \\
\end{array}$} & $1.050^{\circ} \mathrm{C}$ & \multirow{3}{*}{$-0,72$} & 1,71 & 1,00 & 14,08 & 137,25 & cukup padat \\
\hline & & & & & & & \\
\hline & $1.150^{\circ} \mathrm{C}$ & & 4,60 & 3,88 & 9,23 & 200,41 & sudah padat \\
\hline \multirow{2}{*}{$\begin{array}{c}\text { Lempung Campang } \\
+ \\
\text { Tuf feldspatik } \\
\text { Sukarami } \\
\text { (Prototipe 3) } \\
\end{array}$} & $1.050^{\circ} \mathrm{C}$ & \multirow[b]{2}{*}{$-0,08$} & 5,31 & 5,22 & 13,59 & 191,00 & cukup padat \\
\hline & $1.150^{\circ} \mathrm{C}$ & & 10,65 & 10,59 & 6,01 & 240,87 & sudah padat \\
\hline \multirow{2}{*}{$\begin{array}{c}\text { Lempung Sipin } \\
+ \\
\text { Tuf feldspatik Pelangki } \\
\text { (Prototipe 4) }\end{array}$} & $1.050^{\circ} \mathrm{C}$ & \multirow{2}{*}{0,52} & 4,47 & 3,93 & 12,47 & 136,73 & kurang padat \\
\hline & $1.150^{\circ} \mathrm{C}$ & & 6,77 & 6,31 & 7,82 & 156,39 & sudah padat \\
\hline
\end{tabular}

* Nilai susut negative (-) artinya sampel mengembang (tidak menyusut)

SK : susut kering; SB : susut bakar; SJ : susut jumlah; PA : peresapan air 
Dengan memanfaatkan potensi sumber daya alam seperti lempung dan felspar yang tersebar di daerah penelitian, diharapkan dapat memberikan kontribusi pada kemajuan industri keramik, baik di daerah Kabupaten Ogan Komering Ulu Selatan maupun daerah lainnya, sehingga di masa depan industri ini terus tumbuh baik dalam kapasitas maupun tipe dan desain produk yang semakin berdaya saing tinggi.

\section{UCAPAN TERIMAKASIH}

Pada kesempatan ini penulis mengucapkan terima kasih kepada Kepala Pusat Sumber Daya Geologi dan kepada tim editor yang telah memberikan saran dan koreksinya sehingga makalah ini dapat diterbitkan

\section{DAFTAR PUSTAKA}

Bukit, A., Sembiring, H. dan Sudrajat, 1994. Pemanfaatan Feldspar Dan Lempung Di Daerah Padang Ratu Dan Sekitarnya. Pusat Penelitian Dan Pengembangan Geoteknologi LIPI, Bandung.

Utomo, A. M., 2007. Wawasan dan Tijauan Seni Keramik. ISI Denpasar, Bali

Aristianto M.M.B., 1982. Proses Pembuatan Keramik. Balai Besar Penelitian Dan Pengembangan Industri Keramik, Badan Penelitian Dan Pengembangan Industri, Departemen Perindustrian.

Anonim, 2009. Roadmap Industri Keramik. Direktorat Jenderal Industri Agro dan Kimia, Departemen Perindustrian, Jakarta

Barry. C.C., Grant. N. M., 2007. Ceramic Materials : Science and Engineering. Springer, Berlin

Caruta. B. M., 2006. Ceramics And Composite Materials : New Research. Nova Science Publisher, New York

Gafoer, S., Amin, T.C. dan Pardede, R., 1993. Peta Geologi Lembar Baturaja,
Sumatera skala 1 : 250.000. Pusat Penelitian Dan Pengembangan Geologi, Bandung.

http://www.kemenperin.go.id/artikel/8999/Kapa sitas-Industri-Keramik-Terus-Diperluas diunduh pada tanggal 5 Juni 2015.

http://www.bbk.go.id/index.php/berita/view/55// ndustri-Keramik-Menjadi-UnggulanIndonesia diunduh pada tanggal 7 juni 2015.

Purnomo, H., et al, 1993. Percontohan Pemanfaatan Lempung Overburden Batubara A1 Asal PTBA untuk Bahan Bangunan, Tanjung Enim, Sumatera Selatan. Proyek Pengembangan Teknologi Pengolahan Bahan Galian, Puslitbang Tekmira, Bandung.

Bormans, P., 2004. Ceramics Are More Than Clay Alone: Raw Materials, Products, Applications. Cambridge International Science Publishing, Cambridge CB1 6AZ, United Kingdom.

Saefudin, R., et al., 2003. Nilai Manfaat Investasi Pengolahan Bahan Galian Felspar Di Lampung Tengah, Lampung. Puslitbang Tekmira, Bandung.

Sukandarrumidi, 1999. Bahan Galian Industri. Gadjah Mada University Press, Yogyakarta.

Sayekti, B., Kusdarto, Parningotan, M. R., Labaik, G., 2012. Prospeksi Mineral Non Logam di Kabupaten Ogan Komering Ulu Selatan, Provinsi Sumatera Selatan. Pusat Sumber Daya Geologi, Badan Geologi, Bandung.

Wikarta, S., 1984. Penyelidikan Pendahuluan Endapan Batugamping Serta Inventarisasi Bahan Galian Tras Di Daerah Sipatuhu Dan Sekitarnya, Kecamatan Banding Agung, Kabupaten Ogan Komering Ulu, Provinsi Sumatera Selatan. Kantor Wilayah Provinsi Sumatera Selatan, Departemen Pertambangan Dan Energi, Palembang.

Zulfikar, Sayekti. B., Kusdarto, Muksin, I., Edwin, F., 2011. Kajian Potensi Bahan Keramik Sumatera Bagian Selatan. Pusat Sumber Daya Geologi, Badan Geologi, Bandung. 



\title{
SIMULASI NUMERIK SISTEM PANAS BUMI GUNUNG TALANG - KILLI KABUPATEN SOLOK, PROVINSI SUMATERA BARAT \\ NUMERICAL SIMULATION OF GUNUNG TALANG-KILLI GEOTHERMAL SYSTEM IN SOLOK REGENCY, WEST SUMATERA PROVINCE
}

\author{
Dikdik Risdianto, Moch. Nurhadi, Muhammad Kholid dan Yuano Rezky \\ Pusat Sumber Daya Geologi \\ Jalan Soekarno-Hatta No. 444, Bandung \\ Email : dikrisdi@yahoo.com
}

Diterima : 2 Maret 2015

Direvisi : 27 April 2015

Disetujui : 28 Mei 2015

\begin{abstract}
ABSTRAK
Simulasi numerik di daerah panas bumi Gunung Talang - Killi menggunakan program simulator TOUGH2 dengan Equation of State (EOS-1), satu fasa, disusun berdasarkan konseptual model hasil survei geologi, geokimia, dan geofisika (3-G) serta pengeboran landaian suhu sumur TLG-1. Parameter yang digunakan antara lain permeabilitas, porositas, konduktivitas panas dan kapasitas panas batuan.

Penyebaran litologi secara lateral dan vertikal disusun berdasarkan grid blok menjadi beberapa lapisan yang mendekati konfigurasi litologi dalam model konseptual. Kondisi inisial dan batas kondisi diberikan berdasarkan data yang tersedia.

Hasil simulasi yang didapatkan setelah dilakukan proses kalkulasi beberapa kali (trial and error) dengan merubah beberapa parameter simulasi dan hasil yang paling baik dikalibrasi dengan hasil pengukuran temperatur sumur pengeboran landaian suhu TLG-1.

Mengingat keterbatasan data yang dimiliki, hasil simulasi ini merupakan proses inisial (permulaan) simulasi untuk sistem panas bumi Gunung Talang - Killi dan masih harus dilakukan update berdasarkan data lanjutan.
\end{abstract}

Kata Kunci : Panas Bumi, Simulasi Numerik, kondisi inisial, natural state, Gunung Talang - Killi, up flow, out flow.

\section{ABSTRACT}

Numerical simulations in Gunung Talang - Killi geothermal area were done by using TOUGH2 simulator program with Equation of State 1 (EOS-1), single phase, and based on a conceptual model of geological, geochemical, geophysical surveys (3 - G) result and also the gradient thermal drilling well TLG-1. The parameters that involved in calculation are permeability, porosity, thermal conductivity and specific heat capacity.

Lithology of study area is distributed laterally and vertically based on grid of blocks and arrayed into several layers similar to the conceptual model. Initial condition and boundary are given based on the available data.

Simulation results are obtained after a process of testing several times by changing some parameters of the simulation and the best results with a calibrated by measured temperature of gradient thermal drilling well TLG-1. Due to the limitation of the data especially deep drilling data, the results of simulation is needed to be updated by advanced data.

Keywords : Geothermal, numeric simulation, initial Condition, natural state, Gunung Talang - Killi, up flow, out flow.

\section{PENDAHULUAN}

Secara administratif daerah penyelidikan panas bumi G. Talang - Killi termasuk dalam wilayah administratif Kabupaten Solok, Provinsi Sumatera Barat, pada koordinat antara $100^{\circ} 36^{\prime} 8$ " - $100^{\circ} 44^{\prime} 8$ " BT dan $0^{\circ} 48^{\prime} 55^{\prime \prime}-0^{\circ} 59^{\prime} 4$ " LS, dengan luas sekitar $15 \mathrm{~km} \times 15 \mathrm{~km}$, terletak di sebelah timurlaut kota Padang, ibukota Provinsi Sumatera Barat, berjarak sekitar $54 \mathrm{~km}$. Lokasi penyelidikan dapat dicapai menggunakan pesawat terbang sampai ke Kota Padang, yaitu Bandar 
Udara Minangkabau, dilanjutkan dengan kendaraan roda empat sampai ke G. Talang dan Bukit Killi.

$$
\text { Tujuan dari simulasi numerik }
$$

sistem panas bumi adalah menguji kemungkinan keberadaan suatu sistem panas bumi yang terbentuk dalam suatu model konseptual. Hal ini sangat penting dilakukan terutama pada suatu daerah panas bumi yang masih belum dieksploitasi (natural state) dan masih belum banyak memiliki data bawah permukaan yang lengkap (pengeboran eksplorasi).

Stratigrafi/litologi daerah panas bumi G. Talang - Killi tersusun oleh batuan vulkanik Kuarter. Morfologi terdiri dari satuan morfologi Kerucut Gunung Talang yang merupakan Puncak Gunungapi Talang, Tubuh Gunung Talang, Perbukitan Vukanik Tua yang berada di bagian barat dan timur Gunung Talang memanjang kearah utara, Perbukitan Terisolir Bukit Kili serta Pedataran yang merupakan depresi Solok (Gambar 1). Dari tua hingga yang termuda daerah ini tersusun oleh satuan metamorf hingga vulkanik produk Gunung Talang (Anonim, 2004). Adapun urutan stratigrafi dari yang tua hingga ke muda adalah :

a. Formasi Tuhur (Trts), tersusun atas batuan malihan/metamorfosa derajat rendah berjenis filit berwana abu-abu gelap-hitam dan sebagaian lapuk berwana coklat-kemerahan, berukurukuran butir lempung-lanau, memperlihatkan foliasi yang jelas, banyak dijumpai kekar-kekar. Batuan malihan ini ditafsirkan sebagai batuan dasar (basement) yang berumur Pra-Tersier.

\section{b. Satuan Vulkanik Tua (QTau),} merupakan batuan vulkanik tak terpisahkan yang tersusun atas lava dan piroklastika, mengindikasikan telah terkena struktur sesar, permeabilitas cukup baik. Satuan ini diperkirakan berumur Kuarter Bawah sampai Tersier Atas (Plistosen - Pliosen).

c. Batuan Vulkanik Bukit Kili (QKLv), disusun oleh batuan beku berwarna abu-abu kemerahan, masif, bertekstur porfiritik kasar, sedangkan batuan penyusun di Bukit Kili Kecil berupa batuan beku berwarna abu-abu terangsedang, masif, bertekstur porfiritik sedangkasar. Interpretasi geologi sementara terhadap Bukit Kili tersebut adalah tubuh batuan beku intrusif atau sisa tubuh kubah vulkanik.

d. Produk Vulkanik Bukit Bakar (QBKv), dapat dibagi menjadi lima satuan batuan yang terdiri dari dua satuan lava dan tiga satuan aliran piroklastika. Secara lebih rinci produk Bukit Bakar ini dari tua ke muda adalah: Satuan Batuan Aliran Piroklastika 1 Bukit Bakar, Satuan Batuan Lava 1 Bukit Bakar, Satuan Aliran Piroklastika 2 Bukit Bakar, Satuan Aliran Piroklastika 3 Bukit Bakar, dan Satuan Lava 2 Bukit Bakar.

\section{e. Produk Vulkanik Danau}

Talang (QDTV), Danau Talang yang ada sekarang ini diduga merupakan danau kawah (crater lake) sebagai sisa pusat erupsi gunungapi Talang Purba. Di sekitar danau ditemukan adanya batuan-batuan vulkanik yang mendukung bahwa Danau Talang tersebut sebagai pusat erupsi, serta dijumpai danau yang berukuran lebih kecil di tenggara Danau Talang berjarak sekitar 500 meter, yang diperkirakan sebagai danau kawah hasil letusan freatik. Pemunculan pusat erupsi ini ditafsirkan dipicu oleh struktur sesar normal Danau Talang yang berarah Barat Laut-Tenggara.

f. Produk Vulkanik Batino, diperkirakan sebagai bagian dari Gunungapi Talang tua dengan titik tertinggi sekitar 2450 meter di atas permukaan laut. Tersusun oleh perselingan antara piroklastika dan lava. Dalam sejarah letusannya satuan batuan ini dapat dipisahkan menjadi Satuan Lava 1 Batino $\left(\mathrm{QBI}_{1}\right)$, Satuan Aliran Piroklastika (QBa) dan Satuan Lava 2 Batino $\left(\mathrm{QBI}_{2}\right)$.

g. Produk Vulkanik Jantan, merupakan kerucut termuda dari Gunungapi Talang, yang mempunyai ketinggian sekitar 2600 meter di atas permukaan laut. Penyebaran batuan vulkanik produk Gunung Jantan ini dikontrol oleh keberadaan struktur baik sesar maupun sisa dinding kawah Batino. Struktur sesar Danau Talang dan sesar Batu Berjanjang sangat berperan dalam 


\section{MAKALAH ILMIAH}

mengontrol penyebaran satuan batuan produk Gunung Jantan di bagian Utara, serta salah satu sesar tersebut (sesar Batu Berjanjang) merupakan media keluarnya mata air panas di daerah Gunung Talang tersebut.

\section{h. Endapan Permukaan}

(QLh), satuan endapan permukaan atau sekunder ini tersusun oleh materialmaterial vulkanik tua yang terombakan yang bersifat laharik.

i. Pola-pola struktur geologi dan kelurusan-kelurusan yang pada umumnya berarah baratlaut-tenggara dan juga dijumpai struktur-struktur vulkanik berupa kawah bekas letusan gunungapi. Struktur yang berkembang di daerah Gunung Talang - Bukit Kili terdiri dari struktur sesar/ patahan dan struktur vulkanik berupa kawah bekas hasil letusan gunungapi. Struktur sesar tersebut berjenis sesar normal yang umumnya berarah baratlaut-tenggara dan sebagian berarah utara-selatan serta baratdayatimurlaut (Gambar 1).

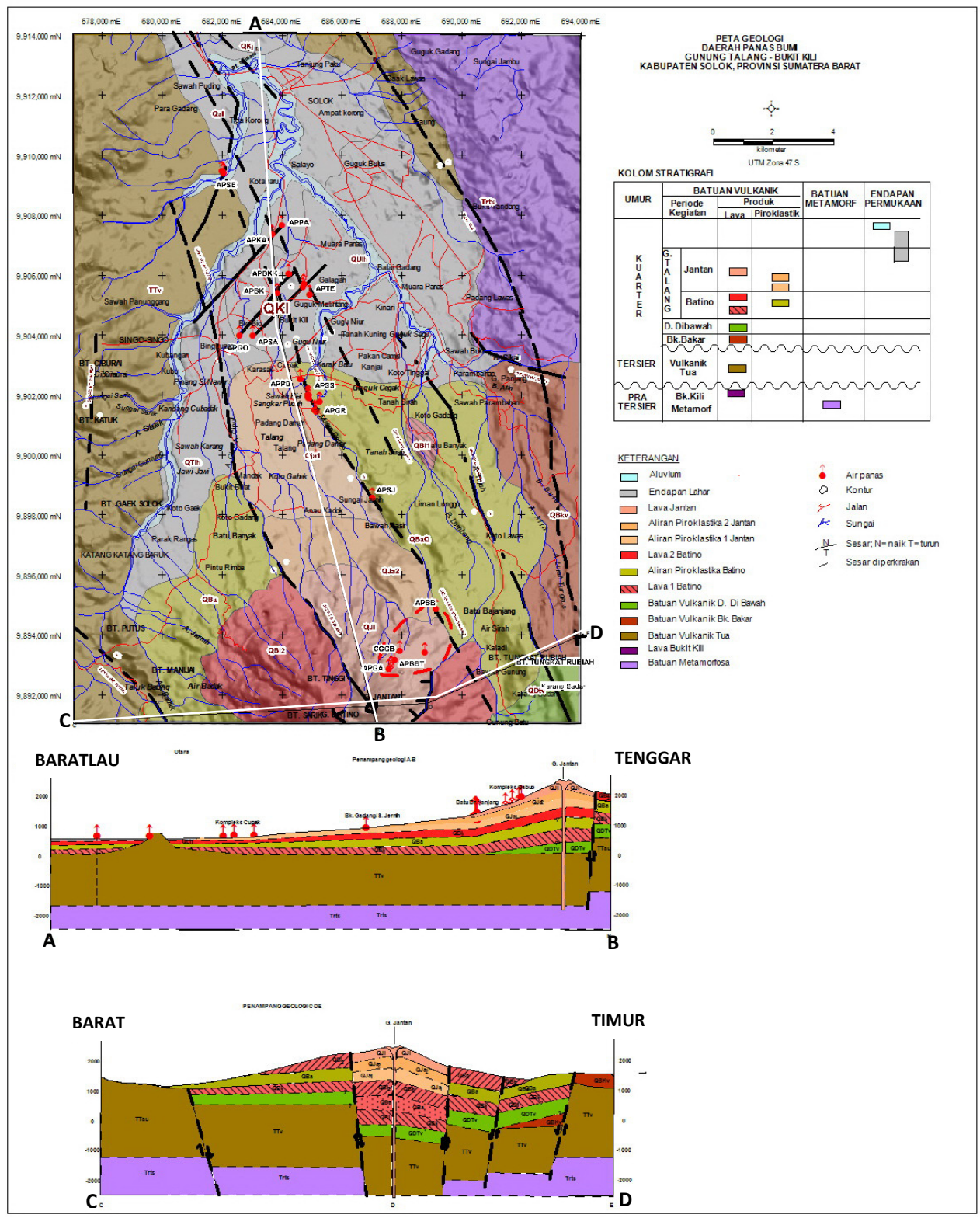

Gambar 1. Peta Geologi daerah panas bumi G. Talang - Killi, Kab. Solok, Sumatera Barat (Anonim, 2003; Anonim, 2004) 


\section{MAKALAH ILMIAH}

Beberapa manifestasi berupa mata air panas dijumpai di lokasi ini, Manifestasi panas bumi utama berupa mata air panas yang tersebar dari kaki Gunung Talang hingga Bukit Killi di sebelah utara. Temperatur air panas berkisar antara 40 hingga $53^{\circ} \mathrm{C}$ dengan $\mathrm{pH}$ netral. Fumarol dan batuan ubahan sangat intensif ditemukan di Gabuo Bawah dan Gabuo Atas, temperatur fumarol antara $80^{\circ} \mathrm{C}$ hingga $96^{\circ} \mathrm{C}$, setempat terdapat endapan belerang.

Hasil perhitungan dengan menggunakan geothermometer gas $\left(\mathrm{CO}_{2} / \mathrm{Ar}\right)$ dari fumarol di Gabuo Atas menunjukkan bahwa temperatur reservoir sebesar $227^{\circ} \mathrm{C}$, atau termasuk dalam sistem panas bumi entalpi tinggi (Anonim, 2003). Estimasi penyebaran dan dimensi reservoir diperoleh dari data hasil pengukuran Magnetotelurik (MT) dimana puncak reservoir berada pada kedalaman mencapai 2500 m (Anonim, 2012).

\section{Model Konseptual}

Model konseptual adalah suatu gambaran model berdasarkan dari datadata geosain yang dihasilkan dari survei geologi, geokimia dan geofisika serta pengeboran. Gambar 2 adalah model konseptual untuk sistem panas bumi $G$. Talang - Killi (Anonim, 2003). Secara umum sistem panas bumi G. Talang - Killi berasosiasi dengan produk komplek gunung api $G$. Talang yang berumur Kuarter, zona upflow berada di lereng gunung komplek G. Talang, aliran fluida secara lateral dikontrol oleh struktur utama yang berarah relatif baratlaut-tenggara hingga keluar sebagai kelompok manifestasi permukaan di daerah Bukit Killi.

Lapisan resistivitas rendah diinterpretasikan sebagai lapisan cap rock berdasarkan hasil survei magnetotellirik, puncak reservoir diperkirakan berada di kedalaman mencapai $2500 \mathrm{~m}$, sedangkan sumber panas atau heat sources diperkirakan berasal dari aktivitas G. Talang (Anonim, 2012).

\section{Simulasi Numerik}

Sebagaimana dikemukakan di atas, tujuan simulasi numerik adalah menguji suatu konseptual model yang dihasilkan dari berbagai survei geosains (geologi, geokimia dan geofisik). Umumnya simulasi numerik atau simulasi reservoir dilakukan pada lapangan-

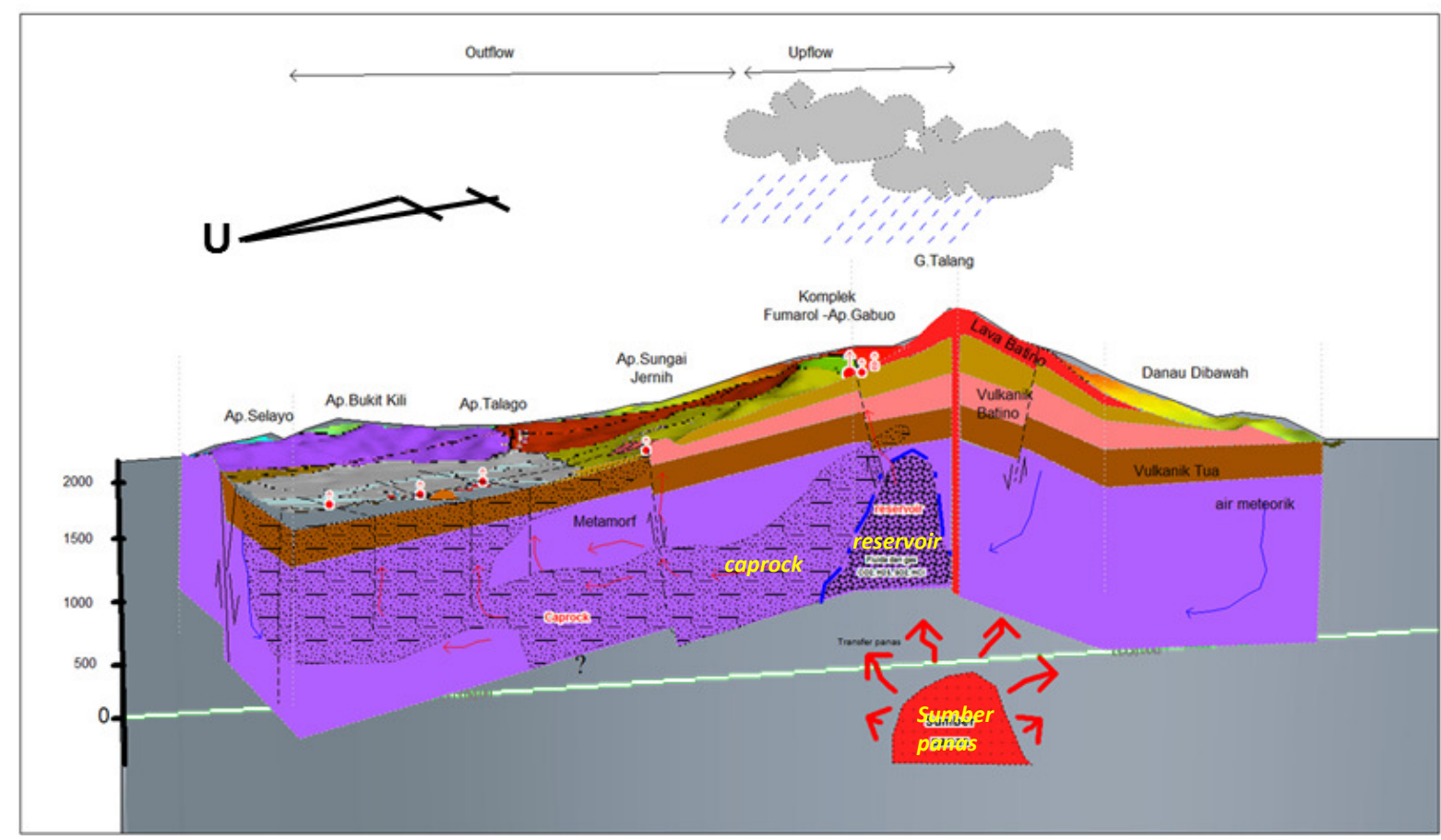

Gambar 2. Model konseptual Sistem Panas Bumi G. Talang - Killi (Anonim, 2004) 
lapangan panas bumi yang siap dikembangkan, pada lapangan-lapangan ini tujuan simulasi ini lebih diarahkan pada prediksi besaran produksi dari sumursumur produksi, sehingga hasil simulasi ini bisa menunjang skenario pengembangan lapangan panas bumi.

Mengingat keterbatasan data yang ada, pada kasus simulasi numerik Daerah Gunung Talang - Killi ini, tujuan simulasi hanya menguji model konseptual hasil survei geosain. Temperatur hasil simulasi nemurik dikalibrasi dengan kurva temperature hasil pengukuran dari sumur landaian suhu TLG-01. Meskipun validitas hasil simulasi ini belum maksimal, tetapi dapat memberikan gambaran awal dari suatu sistem panas bumi Gunung Talang - Killi. Model konseptual 3-D disusun berdasarkan parameter-parameter sifat litologi yang dipandu oleh penyebaran litologi secara lateral dan vertikal dari model konseptual. Parameter numerik 3-D disesuaikan berulang kali (trial and error) hingga didapatkan kondisi reservoir natural state yang sesuai dengan profil temperatur sumur landaian suhu TLG-1.

\section{Sistem Kisi-Kisi (Grid) Dan Perlapisan}

Pada prinsipnya, metode simulasi numerik adalah membuat parameterparameter geosain ke dalam sistem blok kisi-kisi. Simulasi ini dibuat dengan dimensi kisi-kisi $15 \mathrm{~km}$ (arah barat-timur) dan 15,5 km (arah utara-selatan). Elevasi puncak blok kisi-kisi berada pada $500 \mathrm{~m}$ di atas permukaan laut (Gambar 3). Tebal perlapisan blok-blok dengan kisi-kisi bervariasi antara 250 hingga $500 \mathrm{~m}$. Penentuan dimensi grid dibuat berdasarkan kondisi geosain dari konseptual model, umumnya di zona-zona struktur dan manifestasi serta titik pengeboran dimensi grid bisa dipersempit hingga mencapai ukuran $500 \mathrm{~m}$ x $500 \mathrm{~m}$.

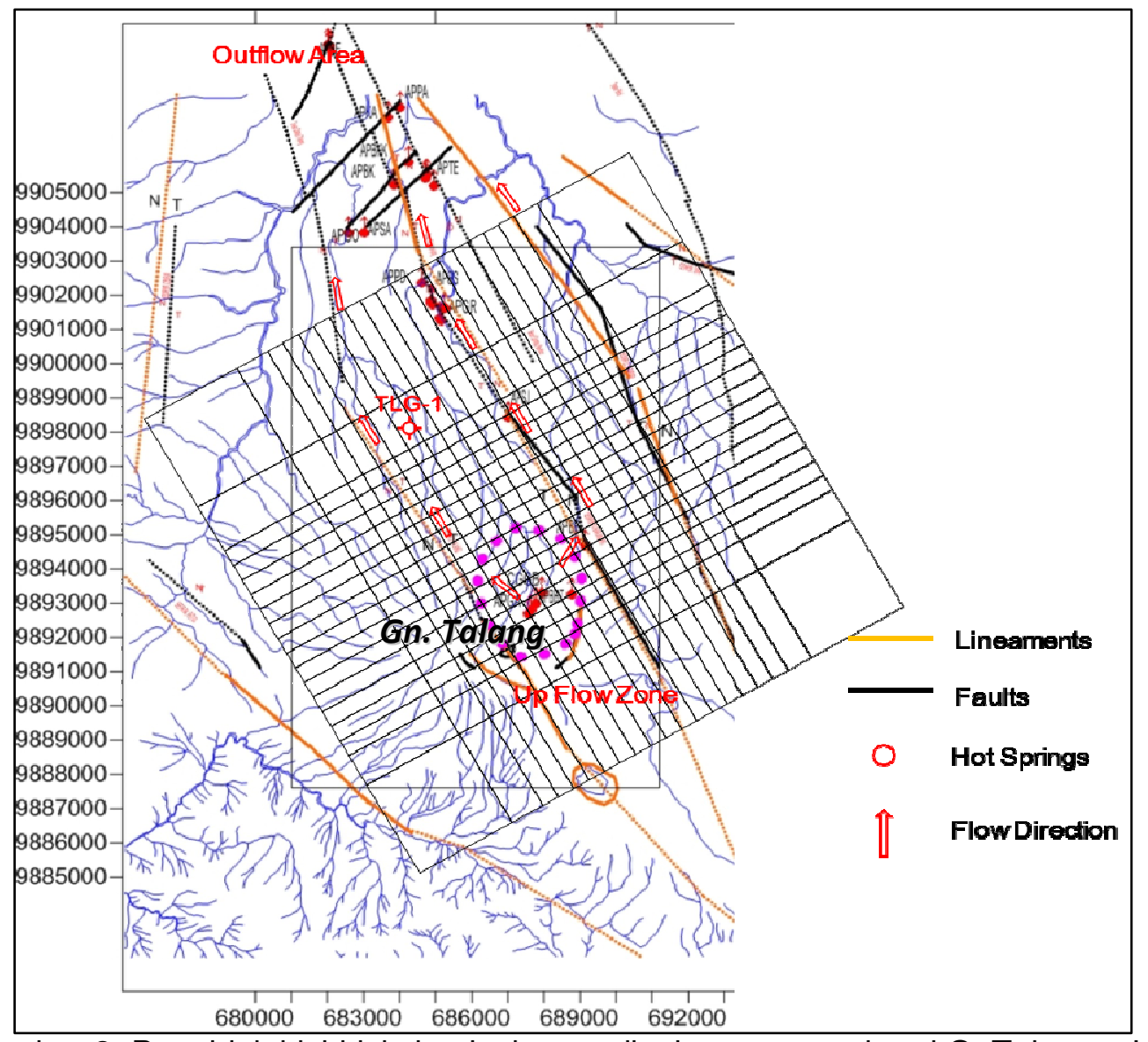

Gambar 3. Peta blok kisi-kisi simulasi numerik sistem panas bumi G. Talang - Killi

(UTM 48 S) 
Proses simulasi numerik dilakukan dengan program simulasi TOUGH2 v.2, dilengkapi oleh Equation of State 1 (EOS 1), dengan asumsi sistem terdiri dari satu fasa (cair). Sebelum melakukan proses kalkulasi dengan simulator TOUGH2 terlebih dahulu dilakukan pemrosesan dengan program Pre-Post Processor yang merupakan program Macro Spread Sheet Microsoft Excel.

\section{Parameter Litologi}

Parameter-parameter petrofisika yang digunakan dalam proses simulasi terdiri dari densitas, permeabilitas, konduktivitas termal, porositas dan kandungan panas. Satuan parameterparameter ini semua dinyatakan dalam satuan SI (Sistem International). Parameter-parameter ini menyebar secara lateral dan vertikal berdasarkan model konseptual yang digunakan. Lapisan reservoir atau zona-zona struktur sesar memiliki sifat permeabilitas relatif lebih tinggi dibandingkan lainnya, sebaliknya untuk lapisan penudung (cap rock) memiliki nilai permeabilitas jauh lebih rendah, sehingga fluida tidak bisa melewati lapisan ini. Parameter permeabilitas yang digunakan dalam simulasi ini berkisar antara $0,01 \times 10^{-5} \mathrm{~m}^{2}$ hingga $100 \times 10^{-5} \mathrm{~m}^{2}\left(1 \times 10^{-5} \mathrm{~m}^{2}=1\right.$ milli Darcy).

Parameter lainnya seperti porositas yang diasumsikan bersifat homogen yaitu sekitar 10\%, densitas batuan juga dianggap homogen yaitu 2500 $\mathrm{kg} / \mathrm{m}^{3}$ yang mewakilli litologi vulkanik dan sedimen, termal konduktivitas dan kapasitas panas batuan juga diestimasi homogen yaitu masing-masing $2,2 \mathrm{~W} / \mathrm{m}^{\circ} \mathrm{C}$ dan $830 \mathrm{~J} / \mathrm{kg}{ }^{\circ} \mathrm{C}$. Tabel 1 memperlihatkan parameter litologi yang digunakan dalam simulasi.

\section{Kondisi Inisial Dan Kondisi Batas}

Simulasi pada kondisi natural state adalah mensimulasikan kondisi sistem pada saat belum diproduksi atau dieksploitasi, Simulasi ini dijalankan dengan rentang waktu sekitar satu juta tahun, hal ini diharapkan sistem sudah mencapai kesetimbangan (Nakatani et.al, 2007).

Kondisi inisial adalah kondisi awal sebelum terbentuk sistem panas bumi. Kondisi batas yang diterapkan dalam simulasi ini adalah tekanan yang di asumsikan bergradasi mulai dari sisi utara dan membesar nilainya ke arah sisi selatan, mulai dari 1 bar hingga 20 bar. Penentuan nilai tekanan ini didasarkan pada tekanan hidrostatik (Noorollahi dkk., 2011). Dengan adanya perbedaan tekanan ini fluida akan mengalir dari tenggara yaitu dari tubuh Gunung Talang ke arah baratlaut menuju ke daerah Bukit Killi. Sedangkan untuk temperatur kondisi inisial di puncak blok kisi-kisi diasumsikan homogen yaitu sebesar $26^{\circ} \mathrm{C}$.

Selain itu di bagian sekeliling blok kisi-kisi, yang terletak di luar sistem panas bumi G. Talang - Killi penyebaran temperatur secara vertikal mengikuti gradien temperatur normal yaitu sekitar $4^{\circ} \mathrm{C} / 100 \mathrm{~m}$ dan besarnya tekanan mengikuti tekanan hidrostatik yang merupakan fungsi dari kedalaman dan densitas air.

Tabel 1. Parameter Litologi Yang Digunakan Dalam Proses Simulasi

\begin{tabular}{|c|c|c|c|c|c|c|c|}
\hline \multirow[t]{3}{*}{ Material } & \multirow{2}{*}{$\begin{array}{c}\text { Densitas } \\
(\mathrm{kg} / \mathrm{m} 3) \\
\end{array}$} & \multirow[t]{3}{*}{ Porositas } & \multirow{2}{*}{\multicolumn{3}{|c|}{$\begin{array}{c}\text { Permeabilitas } \\
(\text { miliDarcy }(\mathrm{mD}))\end{array}$}} & \multirow{3}{*}{$\begin{array}{l}\begin{array}{l}\text { Kond. } \\
\text { Panas }\end{array} \\
\left(\mathrm{W} / \mathrm{m}^{\circ} \mathrm{C}\right) \\
\end{array}$} & \multirow{3}{*}{$\begin{array}{c}\text { Kap. } \\
\text { Panas } \\
\left(\mathrm{J} / \mathrm{kg}^{\circ} \mathrm{C}\right) \\
\end{array}$} \\
\hline & & & & & & & \\
\hline & & & $X$ & $\mathrm{Y}$ & Z & & \\
\hline Sesar/fracture & 2500 & 0,10 & 100 & 100 & 50 & 2,20 & 830 \\
\hline Sedimen & 2500 & 0,10 & 5 & 5 & 2,5 & 2,20 & 830 \\
\hline Caprock & 2500 & 0,10 & 0,01 & 0,01 & 0,005 & 2,20 & 830 \\
\hline Malihan & 2500 & 0,10 & 2 & 2 & 1 & 2,20 & 830 \\
\hline $\begin{array}{l}\text { Produk } \\
\text { Talang }\end{array}$ & 2500 & 0,10 & 10 & 10 & 5 & 2,20 & 830 \\
\hline
\end{tabular}




\section{MAKALAH ILMIAH}

Sumber panas (heat sink) ditempatkan tepat di bawah zona reservoir dengan temperatur $230{ }^{\circ} \mathrm{C}$ (geotermometer gas).

\section{PEMBAHASAN HASIL SIMULASI}

Hasil simulasi merupakan hasil terbaik hasil coba-coba secara beberapa kali, dengan cara memodifikasi nilai-nilai parameter serta geometri dari blok kisi-kisi yang dibuat. Hasil ini dikalibrasi oleh hasil pengukuran temperatur sumur pengeboran landaian suhu TLG-1 dan manifestasi yang terbentuk di permukaan hasil yang paling sesuai (matching) dengan hasil pengukuran yang dianggap mendekati sistem yang disimulasikan.

Gambar 4 memperlihatkan sebaran temperatur hasil simulasi untuk tiap elevasi blok kisi-kisi. Terlihat bahwa secara umum sistem panas bumi $G$. Talang - Killi berada di tubuh Gunung Talang. Dengan adanya struktur yang berarah hampir baratlaut - tenggara, maka fluida akan mengalir ke arah baratlaut ke daerah Bukit Killi dan keluar ke permukaan sebagai komplek manifestasi mata air panas.

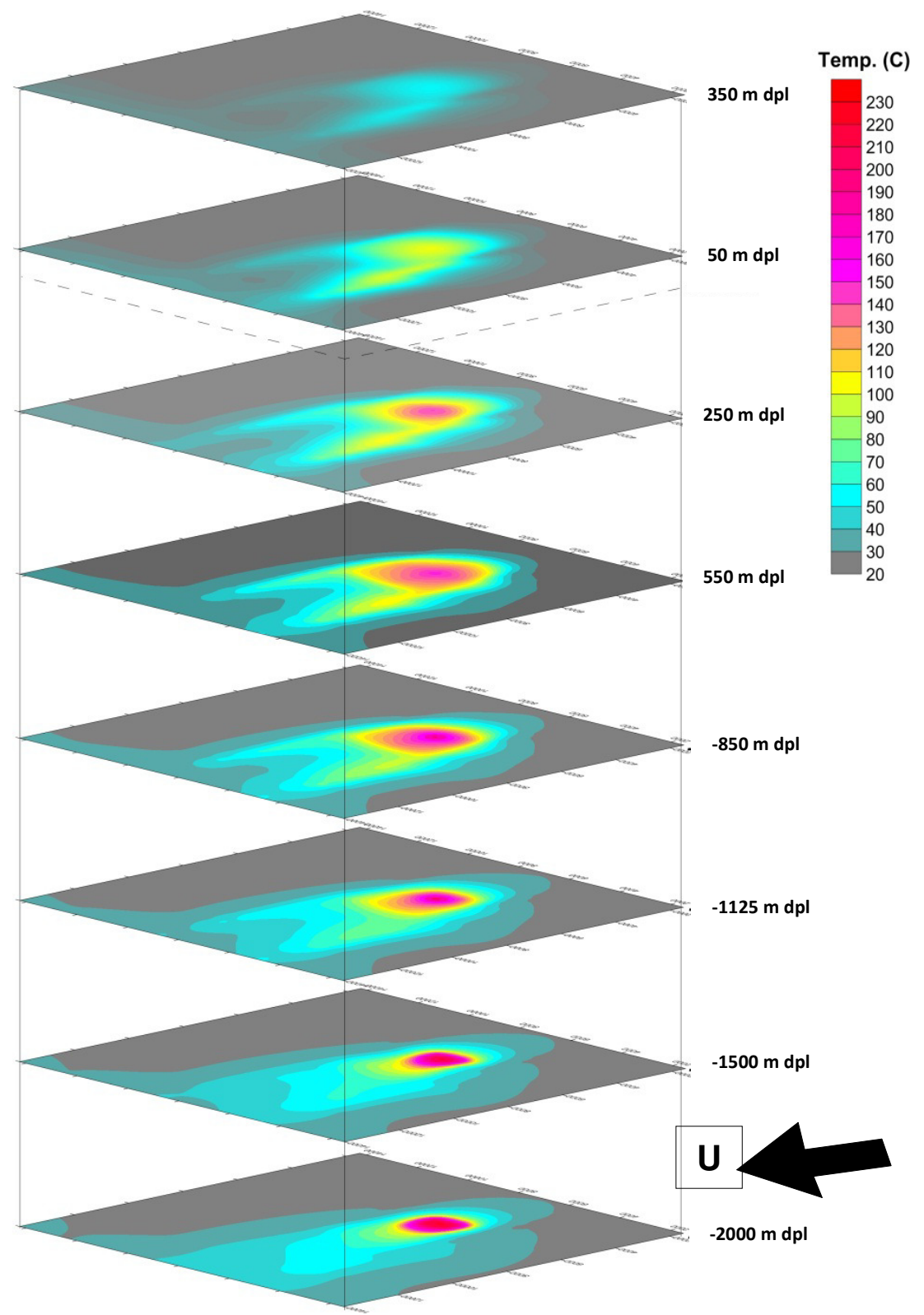

Gambar 4. Distribusi temperatur pada elevasi 350 m hingga -2000 m 


\section{MAKALAH ILMIAH}

Gambar 5 adalah komparasi dari distribusi temperatur secara vertikal antara hasil simulasi dengan hasil pengukuran temperatur di sumur landaian suhu TLG-1, yang memperlihatkan adanya kesesuaian antara hasil pengukuran dan simulasi dimulai dari permukaan $(800 \mathrm{~m}$ dpl) hingga dasar sumur $(0 \mathrm{~m} d p l)$, sedangkan hasil simulasi dimulai dari elevasi $350 \mathrm{~m}$ dpl, tetapi keduanya memiliki kecenderungan yang sama. Profil temperatur sumur TLG-01 menunjukkan bahwa landaian suhu tidak menunjukkan anomali, hal ini ditunjukkan dengan landainya profil temperatur terhadap kedalaman dan menunjukkan bahwa sumur TLG-01 berada di zona outflow.
Gambar 6 memperlihatkan penampang yang melewati sistem panas bumi G. Talang - Killi, arah aliran fluida panas bumi secara umum bergerak secara vertikal di daerah upflow dan bergerak secara lateral menuju kearah baratlaut dan tenggara (outflow). Zona upflow berada di bawah komplek Gunung Talang yaitu di daerah Gabuo atas ditandai dengan adanya zona yang bersifat permeabel sedangkan zona outflow berada di lereng baratlaut komplek Gunung Talang yang ditandai dengan terbentuknya komplek mata air panas dan hangat.

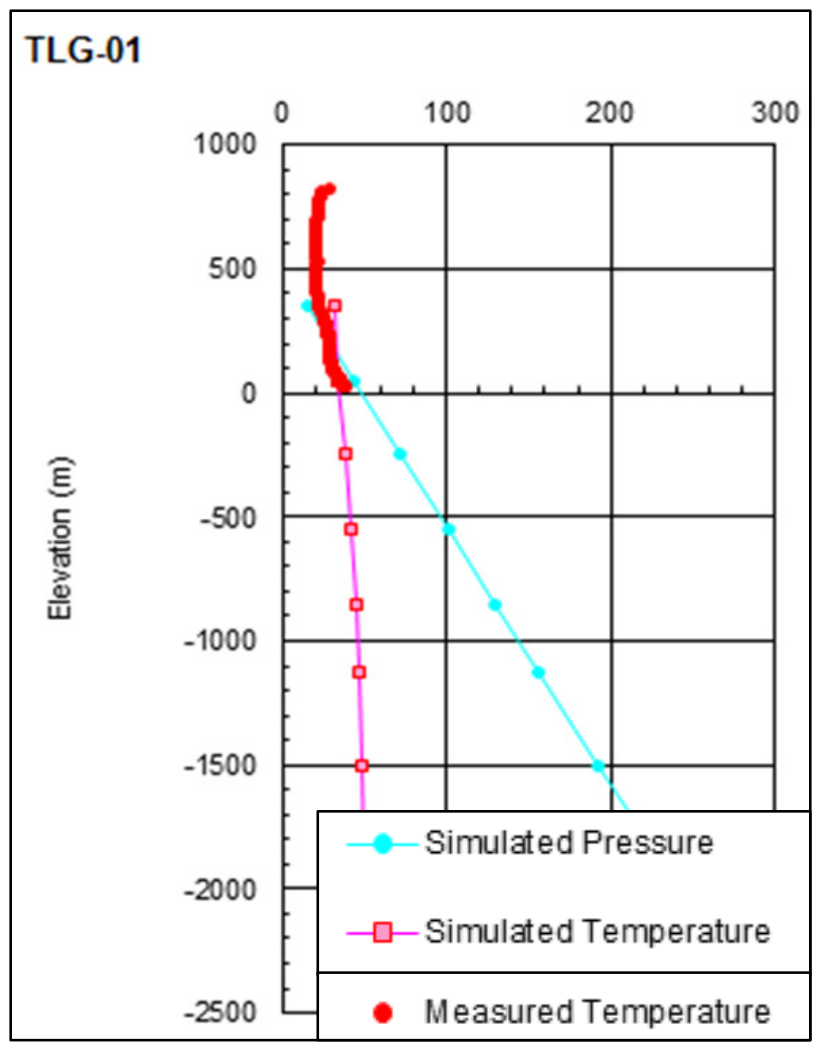

Gambar 5. Komparasi Hasil Simulasi Dengan Hasil Pengukuran Downhole Temperatur Sumur Landaian Suhu TLG-01 


\section{MAKALAH ILMIAH}

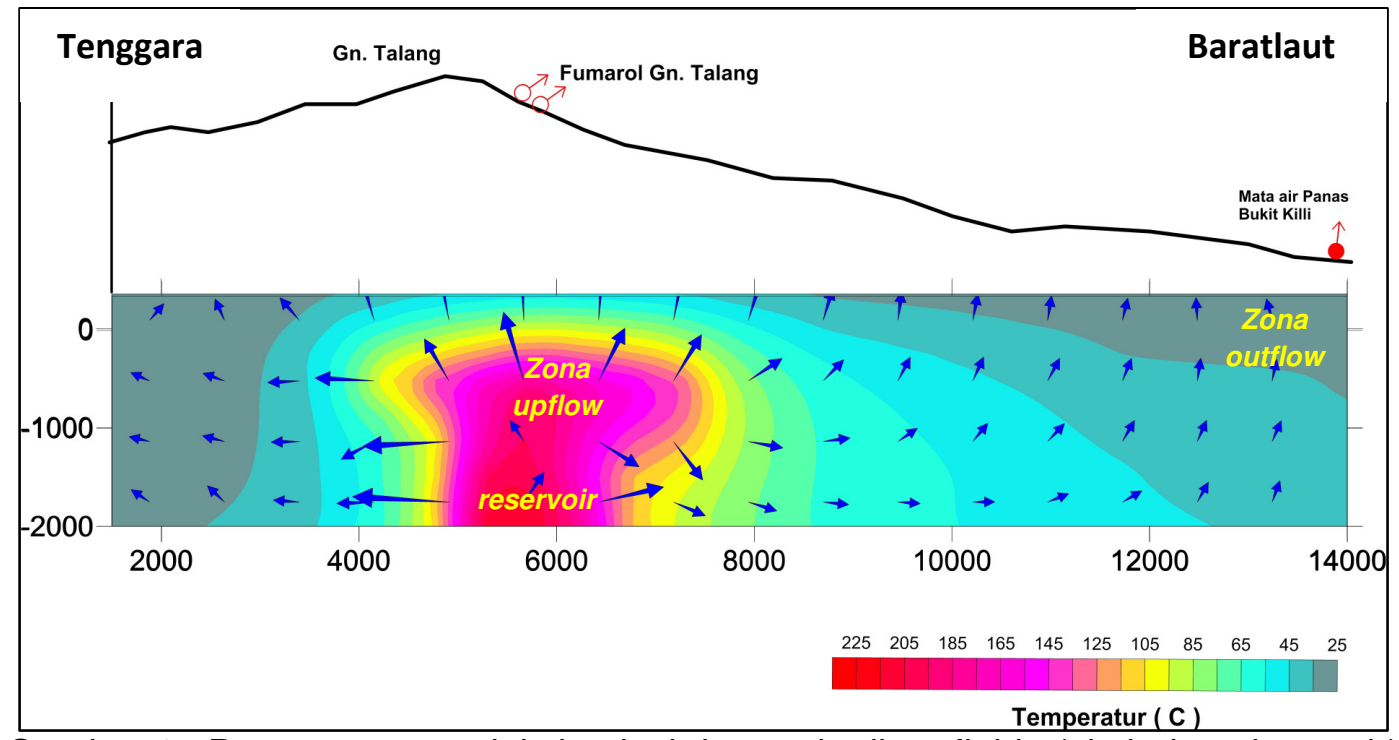

Gambar 6. Penampang model simulasi dan arah aliran fluida (simbol anak panah)

\section{KESIMPULAN}

Simulasi numerik sistem panas bumi G. Talang - Killi merupakan bentuk dari proses tranformasi suatu model konseptual ke dalam bentuk data numerik, hasil kesesuaian (matching) hasil simulasi dengan data pengukuran yang paling sesuai (matching) adalah merupakan hasil yang mendekati sistem yang disimulasikan.

Dalam simulasi sistem panas bumi G. Talang - Killi data-data pengukuran bawah permukaan masih sangat terbatas sehingga hasil yang didapat masih perlu dilengkapi (update) dengan data-data pengukuran sumur pengeboran eksplorasi. Meskipun demikian, hasil ini diharapkan akan menjadi inisiasi dari simulasi numerik tahap lebih lanjut.

Hasil simulasi menunjukkan bahwa daerah upflow sistem panas bumi Gunung Talang-Killi berada di tubuh Gunung Talang dan fluida mengalir secara lateral kearah baratlaut dan tenggara (outflow).

\section{UCAPAN TERIMAKASIH}

Penulis ucapkan terima kasih kepada semua pihak yang mendukung proses penulisan tulisan ini, terutama kepada para tim survei geosain yang telah menghasilkan data-data sebagai bahan untuk simulasi, juga kepada Dr. Hiroyuki Tokita dan Dr. Koichiro Fukuoka yang telah berbagi pengetahuan tentang simulasi numerik dalam program kerja sama antara Badan Geologi dalam hal ini Pusat Sumber Daya Geologi dengan JICA.

\section{DAFTAR PUSTAKA}

Anonim. 2003. Survei Terpadu Geologi, Geokimia dan Geofisika Daerah Panas Bumi G. Talang, Kab. Solok, Sumatera Barat, Pusat Sumber Daya Geologi, Badan Geologi. (tidak dipublikasikan)

Anonim. 2004. Survei Terpadu Geologi, Geokimia dan Geofisika Daerah Panas Bumi Bukit Killi, Kab. Solok, Sumatera Barat, Pusat Sumber Daya Geologi, Badan Geologi. (tidak dipublikasikan)

Anonim. 2012. Survei Pengeboran Landaian Suhu Daerah Panas Bumi Gunung Talang - Killi, Pusat Sumber Daya Geologi, Badan Geologi. (tidak dipublikasikan)

Anonim. 2012. Survei Magnetotellurik (MT) Daerah Panas Bumi G. Talang - Killi, Kab. Solok, Sumatera Barat, Pusat Sumber Daya Geologi, Badan Geologi. (tidak dipublikasikan)

Nakatani, A., Itoi, R., Gotoh, H. and Tanaka, T., 2007, Development of Numerical Model of Takigami Geothermal Reservoir, Kyushu, Japan, Using iTOUGH2 Simulator, Proceedings, $29^{\text {th }}$ NZ Geothermal Workshop. 


\section{MAKALAH ILMIAH}

Nicholson, K., 1993, Geothermal Fluids, Chemistry and Exploration Technique, Springer Verlag, inc., Berlin.

Noorollahi, Y., Itoi, R., 2011. Numerical simulation of Northwest Sabalan geothermal reservoir, Iran. World Renewable Congress 2011, Sweden.

Pruess, K., Oldenburg, C., Moridis, G., 1999, TOUGH2 User's Guide, Version 2.0, Lawrence Berkeley National Laboratory, Report LBNL 43134, Berkeley, CA, USA.
Risdianto, D., Hermawan, D., Kusnadi, D., 2013. Simulasi Numerik Sistem Panas Bumi Bittuang, Kabupaten Tanatoraja, Sulawesi Selatan. Bulletin Sumber Daya Geologi, Volume 8, No.3 Nov. 2013.

Wisnandary, C. M., and Alamsyah, O., 2012. Zero Generation of Muara Laboh Numerical Model: Role of Heat Loss and Shallow Wells Data on Preliminary Natural State Modeling, GRC Transactions, Vol. 36. 